PART FIVE

THE ETHNIC MODERN 
Wim van Zanten - 9789004261778

Downloaded from Brill.com04/26/2023 11:15:48AM via free access 
CHAPTER ELEVEN

\title{
MUSICAL ASPECTS OF POPULAR MUSIC AND POP SUNDA IN WEST JAVA
}

\author{
Wim van Zanten
}

\section{Introduction: Sundanese Music and the Technology of Enchantment}

Research on popular music, particularly in the field of cultural studies, has tended to focus on political and sociological aspects, to the exclusion of musical structures and actual sounds. Whereas in most societies musical genres are in the first place classified by social criteria, it is undeniable that also the technicalities of the music play a role: audiences hear the differences between, for instance, jaipongan and degung kawih performances. This is because these musics are produced in different ways, using different instruments, tone material, musical structure, etc.

Alfred Gell made an important contribution to the anthropological study of art by pointing out that the production of art is a technological process. He mentions that there are 'beautiful' things, like beautiful women, beautiful horses and a beautiful sunset. However, art objects are made 'beautiful' by human beings and this requires technology. He criticizes sociologists like Pierre Bourdieu, who do not really look at an art object as a concrete product of human ingenuity, but only elaborately look at the represented symbolic meanings (Gell 1999:162). In contrast, Gell proposes that anthropologists should look at art as a 'component of technology.' We call something an object of art if it is the outcome of a technological process, the kind of processes in which artists are skilled.

Gell (1999:163) considers the different art forms - painting, sculpting, performing arts, literature, etc. - as components of a vast and often not recognized technical system that is essential for the reproduction of human societies. He calls this system the 'technology of enchantment'. The power of art objects results from the technological processes that they embody, the technology of enchantment is based on the enchantment of technology:

The enchantment of technology is the power that technical processes have of casting a spell over us so that we see the real world in an enchanted form. 
I shall address the issue how the technology of enchantment works for creating different forms of popular music in West Java. By which musical techniques do the artists try to let us see the real world in an enchanted form?

One of the important points of discussion will be the distinction between what has locally been called pop Sunda (Sundanese pop) and the other kinds of popular music produced in West Java. Is it useful to restrict the term pop Sunda, as it has been defined in a workshop in 1989, to a fairly limited number of popular musics of West Java?

Obviously the use of the Sundanese language and some of the topics in the song texts are important factors for Sundanese-ness. However, musical features also make that the music may be called 'Sundanese'. For instance, I shall show that in the popular music produced in West Java the bamboo flute does not only still play a significant role in a symbolic way, but also in a music-technical sense: its sound is heard. Does this sound of the bamboo flute in popular music still evoke feelings of sadness and Sundanese-ness, as it is expressed in older Sundanese texts, like 'the sound of the bamboo flute is melancholy', 'the sound of the bamboo flute is plaintive' and 'the bamboo flute and the mouth harp are lamenting'?

The popular music created by the Sundanese composer Koko Koswara since the 1940s clearly uses Sundanese musical principles and the playing style and sound of the zithers is based on Sundanese entertainment music. The popular singer Doel Sumbang includes instrumental interludes with the typical Sundanese bamboo flute in some of the songs. However, at the same time it is undeniable that, after more emphasis on Sundanese musical elements in the 1970s and 1980s, since the 1990s the popular music produced in West Java increasingly uses musical elements from outside West Java and outside Indonesia that are then localized.

In the next section I shall discuss the concept of pop Sunda (Sundanese pop music) as it has been defined in the 1989 workshop in Bandung. Then I shall give some historical notes on popular music and musicians in West Java. This will be followed by an analysis of the musical history of a few songs and critical remarks about the restriction of the term pop Sunda to only a limited number of popular musics. Different performances of the recorded songs Bajing luncat (The jumping squirrel) and Sorban palid (Turban floating down the river) in the last 30-40 years will be the basis of the music-technical discussion. In my analysis I shall mainly make use of

1 See, for instance, Van Zanten (1989:70-1, 105, 211-2). 
popular music disseminated via cassette tapes (MC), VCDs and some audio CDs.

\section{Pop Sunda as a Specific Kind of Popular Music in West Java}

The Sundanese usually distinguish between Indonesian music (karawitan) and music in other parts of the world, in particular Western music (musik). Similarly, in the 1980s a distinction was made between pop Sunda and popular music in West Java that is not necessarily classified as pop Sunda. Pop Sunda, as it has been defined locally, differs from understandings of most other localized 'popular musics', in that a number of genres considered popular, including jaipongan and degung kawih, are relatively close to 'traditional' musical styles and do not feature the Western harmonies, electric guitars, and keyboards found in many (if not most) Indonesian popular music forms of today. There is a lot Sundanese-ness in pop Sunda.

What makes popular music specifically Sundanese, that is, pop Sunda, rather than popular music produced in West Java? This question was discussed at a workshop that took place on 10 June 1989 at the television station in Bandung with the theme 'What is a regional pop song?' (Apa itu lagu pop daerah?; see also Subagio 1989). Although the title was general, the discussion was only addressed to pop Sunda. The participants, consisting of several well-known musicians, composers, scholars of music and writers, agreed that popular Sundanese music is not the same as just popular music using Sundanese song texts; it should also have local colour' in musical terms (Us Tiarsa et al. 1989:63).

Popular music may be classified according to its use of instruments, tone material, and other musical characteristics. For the participants of the workshop, the used tone material was always a very important aspect; it could be one of the Sundanese pentatonic systems (pélog/degung, sorog/madenda, and saléndro), Western diatonic, or some Arabic tone system (Nano Suratno 1989:24-5; Wahyu Wibisana 1989:34; Ading Affandie 1989:54). ${ }^{2}$ Pop music in West Java could make use of Sundanese or diatonic (Western) tone materials, but to be called pop Sunda the general feeling was that it should make use of the Sundanese tone systems (Us Tiarsa et al. 1989:63). The very successful composer of the popular degung kawih music and teacher at the secondary music school (SMKI) in

2 See also Deni Hermawan (2000:74, 80-82) and (2002:27). 
Bandung, Nano Suratno - known as Nano S. - therefore excluded the popular songs Panon hideung, Manuk dadali, Bubuy bulan, and Peuyeum Bandung from 'Sundanese music'. Although these songs were sung in Sundanese, they made use of the Western tone system and were therefore excluded from pop Sunda (Nano Suratno 1989:24).

Nano S. explained that apart from the tone system and instruments used, the older forms of Sundanese music make a fairly limited use of chords: only fifths (kempyung) and fourths (adularas), whereas Western music makes extensive use of all kinds of chords. The 4-beat measures, and phrases ending on the 8th beat (kenong) and 16th beat (goong) are also important musical features. Last but not least the Sundanese vocal ornamentations, including many types of vibratos are special; pop Sunda should definitely not be sung with Western vibrato, because that would sound 'odd' (Nano Suratno 1989:25-7).

The tone system is also connected to the used instruments: Sundanese, Western - like flute, cello, trumpet, electric guitars and keyboard synthesizers - or instruments from other parts of Asia, Africa, or South America. Whereas the pélog tuning of the gamelan degung and the sorog tuning used in other Sundanese ensembles can fairly well be reproduced on Western instruments, based on a division of the octave in 12 equal intervals, the saléndro tuning cannot (Nano Suratno 1989:24-5; Van Zanten 1989:124-6). It should be remarked that the better-quality keyboards could be tuned according to any tone system, if a musician would like to do so. However, I have not heard this, although it seems to be done by the Krakatau band. ${ }^{3}$ It still needs to be systematically investigated how often the tuning of keyboard synthesizers has been adjusted for popular music in West Java, but my impression is that the answer is: seldom, until 2005 almost all keyboards used the Western 12-tone tuning. Nevertheless, it should not be excluded that in the future keyboards may be tuned according to Sundanese tone systems, especially saléndro, on a larger scale.

For our discussion of pop Sunda the remarks made by Deni Hermawan (2002:27) about contemporary music are relevant. Deni Hermawan classifies contemporary music (musik kontemporer) made in West Java, in three categories of compositions:

3 During the discussion of an earlier version of this essay at the KITLV workshop in December 2003, Edwin Jurriëns remarked that the Krakatau band uses keyboards tuned to the saléndro tone system. 
1. Sundanese music by the instruments used, the tone material, and the Sundanese language used in the song texts;

2. both Sundanese and Western music: instruments and tone material are both a mixture of these two music traditions;

3. Western music: Sundanese instruments using Western tone material. ${ }^{4}$

If these categories were applied to popular music in Sunda, most of this would belong to category 2 and pop Sunda as defined by the 1989 workshop would fall in category 1 . In his list Deni Hermawan does not include music with Western instruments and using Western tone material, although such music may still have some Sundanese musical characteristics, like musical patterns and ornamentations.

In this 1989 Bandung workshop 'What is a regional pop song?' the participants agreed that the musical aspects of popular music were very important. There were many kinds of popular music around in Sunda, but much of that did not belong to pop Sunda. However, without any doubt, according to the participants of the 1989 Bandung workshop, the popular genres to be discussed below, jaipongan, degung kawih and Mang Koko's kacapian songs, all belong to pop Sunda. We may ask whether this clear distinction between popular music in West Java and the much smaller subcategory of pop Sunda is still very useful today. In other words, would it not be better to use pop Sunda for a much wider range of popular music with Sundanese characteristics?

\section{Musical Change}

Musical genres are always recreated and changing; therefore the concept of 'authenticity' is not relevant for music. ${ }^{5}$ It is the processes of hybridization, change and continuity that need our attention. How did and do Sundanese musicians and composers include the different musical possibilities in the context of the existing musical forms in West Java to enchant their audiences in and outside West Java?

4 See a similar classification of Balinese musik kontemporer in Harnish (2005:116-7).

5 See for the problem of the concept '(historical) authenticity' in the case of music, for instance, Heins (1975:20) and Stockmann (1988:4-5); for the irrelevance of the concept 'authenticity' in the wider field of intangible cultural heritage see UNESCO's Yamato Declaration in Proceedings (2004:18-21) and Van Zanten (2004:37). 
Already in the beginning of the twentieth century several scholars, both Indonesian and Dutch, expressed fears that the existing older forms of music in Indonesia would soon be replaced by Western music. These fears could, for instance, be heard in 1921 at a congress in Bandung, organized by the Java Instituut that had been established in 1919 to study and develop culture and language in Java. ${ }^{6}$ The main concern of the organizers of this congress was to find ways to stimulate Javanese and Sundanese music. It was felt that the influence of Western music had become a threat: 'Sundanese music would possibly easily be replaced by European music' (Beraadslagingen 1921:296). The well-known Dutch musicologist and researcher of Indonesian music Johann Sebastian Brandts Buijs ${ }^{7}$ said that it was felt that in Java 'the music and also several other forms of art had come to a standstill during the last 50 years or more' and that 'the main course of the paralysis of the arts was most probably the Dutch domination' (Beraadslagingen 1921:284).

Musical experiments with Western instruments in Sundanese, and more generally Indonesian, music had indeed been going on already in the first half of the twentieth century. In Cianjuran music the piano, guitar and violin have been used to accompany the singing, instead of just the kacapi zithers and the suling bamboo flute. Nano S. also mentions the string orchestra (strijkorkest) that was combined with Sundanese instruments like the kacapi , the suling, kendang (drums), gong buyung ('gong' formed by iron plate above big earthenware pot), and the Tanjidor orchestra, consisting mainly of Western brass wind instruments (Nano Suratno 1989:23). The Tanjidor orchestras were integrated into Sundanese culture, especially for procession music during weddings and circumcisions (Image 11.1). ${ }^{8}$

Since the above mentioned congress of the Java Instituut in 1921 the fear that Sundanese music would possibly easily be replaced by European music has regularly been voiced until today. It did not realize. Although some older musics of West Java almost disappeared (for instance, pantun storytelling) and other musics changed considerably (such as gamelan degung), many did not change dramatically and are still existing (such as the sung poetry tembang Sunda Cianjuran, shaken bamboo instruments ensemble angklung, puppet play wayang golék and the reading and reciting of exemplary deeds of Islamic saints manikaban). Moreover, after

\footnotetext{
${ }^{6}$ See, for instance, Mak van Dijk (2007:90-3) for some information on establishing the Java Instituut in 1919, and the study of the music in Java, including West Java, at that time.

7 A curriculum vitae of Brandts Buijs (1879-1939) is given by Ernst Heins (2008).

8 These brass bands were also integrated in similar ways in other parts of Indonesia and the world (see Boonzajer Flaes 1993).
} 


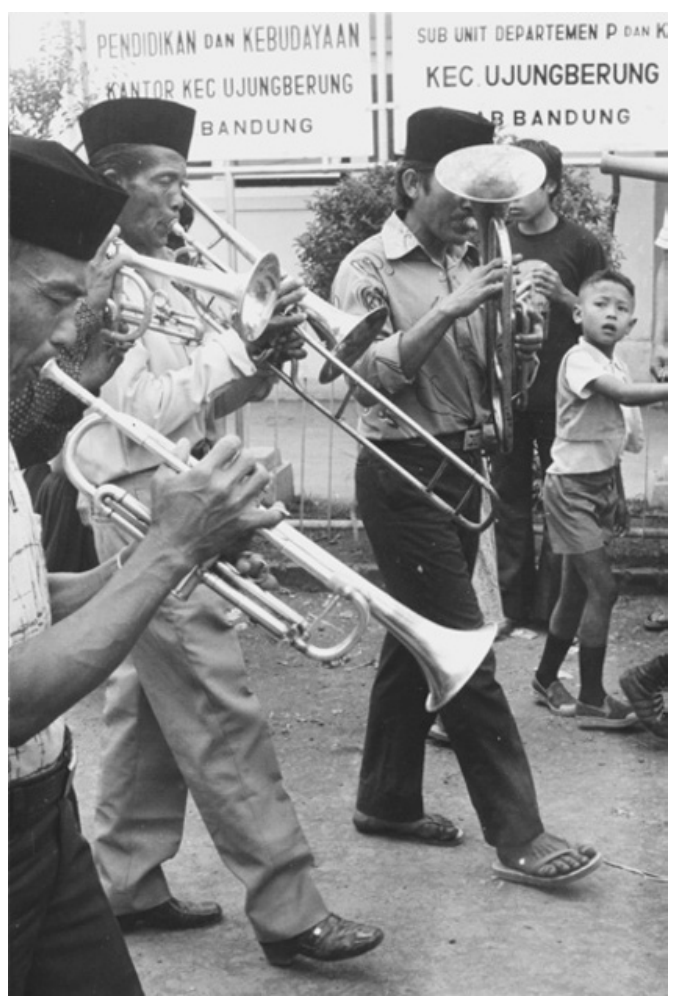

11.1. Tanjidor musicians with Western brass instruments taking part in a bénjang procession in which boys are carried around the villages on the day before their circumcision. Ujungberung, 6 October 1981.

political independence in 1945 new types of music developed. Whereas in the 1950s-1960s Western instruments and musical idiom were often included in popular music, in the 1970s-1980s the new popular genres were more firmly based in the Sundanese music tradition, a development that started in the early 1960s when the Soekarno regime stimulated regional forms of pop music and discouraged / forbade Western pop music. However, since the 199os keyboard synthesizers seem to become increasingly used as the sole accompaniment of the songs, and one reason is that it is cheaper than using a few Sundanese instruments.

The grandfather of today's Sundanese popular music is often understood to be Koko Koswara (1915-1985), usually referred to as Mang9 Koko,

\footnotetext{
${ }^{9}$ Mang means 'uncle' and is used to address men of an elder generation in a friendly way.
} 
whose popular songs for solo voice accompanied by a small gamelan orchestra or kacapi zither (the kacapian music) became widely known in West Java starting in the 1950s. Much of Mang Koko's music used Sundanese musical idiom, but he also created new musical sounds, for instance by introducing new playing techniques on the zither. Initially Mang Koko was inspired by the Jenaka Sunda style (music with humorous texts), but later he developed what was called a 'new style' (wanda anyar) (Deni Hermawan 1996:1, 4, 6). Many of his compositions were love songs, but he is also known for his songs about topical subjects like Zaman atom (The atomic era), Badminton and Beus kota (City bus), ${ }^{10}$ and also some religious songs. ${ }^{11}$

Mang Koko also composed the song 'Tanjung flower' (Kembang Tanjung) to a text by the well-known Sundanese author Wahyu Wibisana, in which a mother sings to her child about his missing father - a guerrilla fighter of the Darul Islam movement that was trying to establish an Islamic state in West Java in the 1950 s-early 196 os $^{12}$ (MC Kembang tanjung panineungan 1984). Mang Koko's music became popular through Bandung radio, gramophone records and, since the 1970s, has often been featured on commercial audio cassettes and in the last years appears on VCDs. In 1971 the Indonesian government honoured Mang Koko with the Satya Lencana Kebudayaan award for his work in music.

In the 1970 and 1980 s two popular genres jaipongan and degung kawih developed, which also became well-known outside the Sundanese area. These genres are definitely considered to belong to pop Sunda, like Mang Koko's music, and they developed out of the existing Sundanese music and dance. Jaipongan is said to have been 'created' by Gugum Gumbira around 1978, and at first he called his new creation of dancing, accompanied by female solo singing with a small gamelan ensemble in saléndro tuning, 'the continuation / development' (terusan) of the ketuk tilu genre (Images 11.2 and 11.3). However, later he decided to give it the name jaipongan, because Sundanese people thought the new genre was too different from the ketuk tilu genre (Hellwig 1989). ${ }^{13}$ Jaipongan became very

\footnotetext{
10 See text of Beus kota in Jurriëns (2004: 117-8); see further Tardi Ruswandi (1996:48).

11 See, for instance, the cassette tape Shalawat Nabi al-Imam; Kawih pupujian Sunda (1995).

12 A Cianjuran song related to the Darul Islam movement is mentioned in Van Zanten (2007:10-1).

13 Hellwig $(1993: 47,48)$ states that 'the beginning of Jaipongan dates back to the late 1970s.' This conflicts with other sources, as it seems to be known earlier under that name. Robert Wessing informed us that the Jaipongan music with dance was already 'hot' and
} 


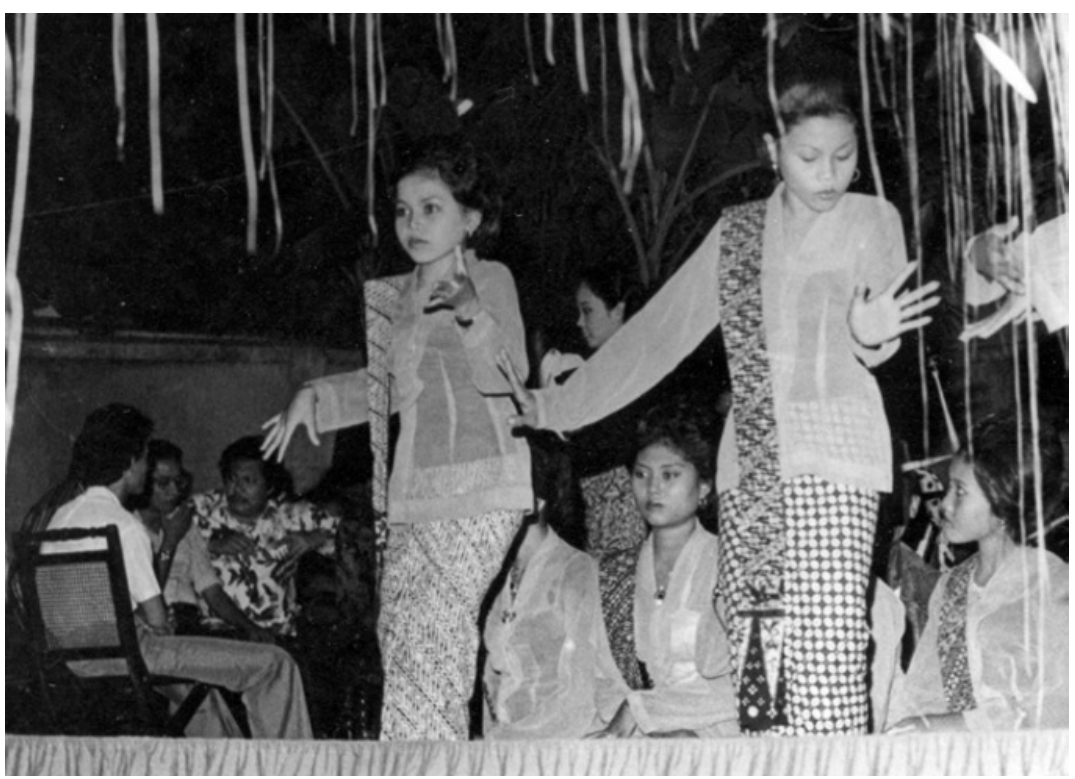

11.2. Women at a party in Jakarta, 14 July 1979. This popular music and dance is related to jaipongan, and in the late 1970 it was also performed at night on the streets of Jakarta [photo by author].

popular in West Java, and was - and still is - played during wedding and circumcision parties.

What is called degung kawih (vocal [gamelan] degung) is the genre that started to develop from the gamelan degung music in the 1950s. Its tuning is in pélog (degung), and therefore different from the gamelan saléndro as used in jaipongan and the wayang plays with three-dimensional puppets (wayang golék). From its creation between 1800 and 1850 the gamelan degung has been used for purely instrumental music and it was only played by men until about $195^{\circ}$ (Van Zanten 1993:150). Since then female vocalists were added to the gamelan degung. ${ }^{14}$ The performance style changed so much that since the 1980 s the popular degung kawih is very

popular in Bandung in 1970 (Barendregt and Van Zanten 2002:74, footnote 8). Tatat Rukmiati and Iyus Rusliana (1994:19-20) mention that Nandang Barmaya 'did pioneering work for the birth of the dance creation that is called the Jaipongan dance' in the middle of the 1970 and that later this was carried on by Gugum Gumbira.

14 The increasing role of female vocalists was a development that in fact had already started in other musics around 1900. 


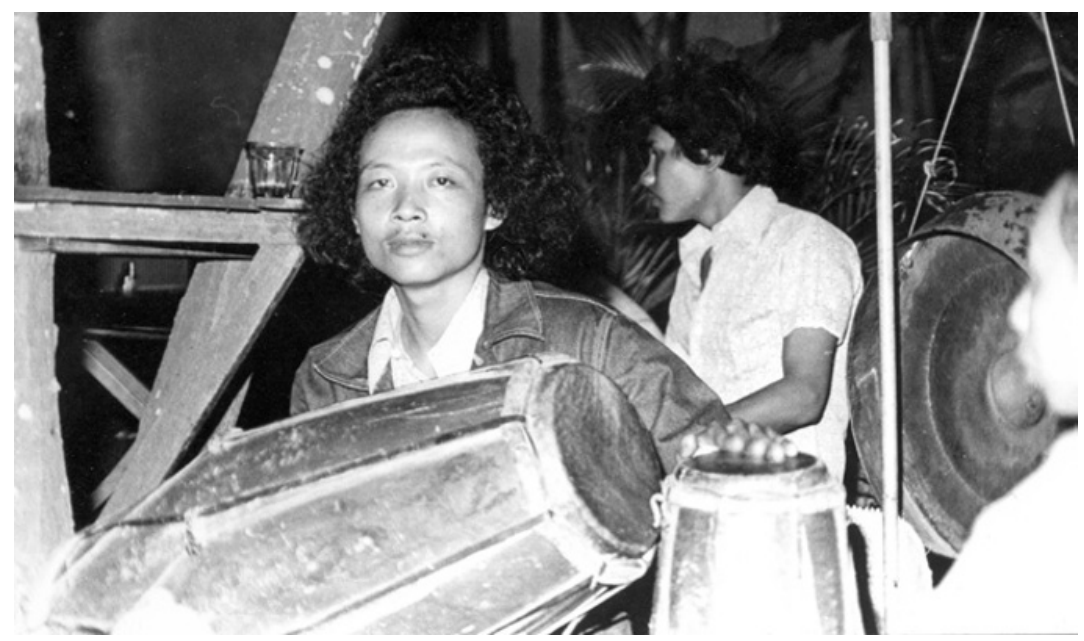

11.3. Drums and a few gamelan instruments accompanying the dancing on Photo 2 at a party in Jakarta, 14 July 1979 [photo by author].

different from the instrumental gamelan degung, which developed in Cianjur and was considered the prestigious gamelan for the regents. Nano S., a student of Mang Koko and teacher at the secondary music school in Bandung (SMKI), composed many songs for degung kawih and some of them became very popular in the 1980 s, also according to the high number of cassette tapes sold (Williams 1989).

Both jaipongan and degung kawih, considered to be pop Sunda according to the 1989 definition, were very much related to the Sundanese music tradition: the traditional instruments (basically gamelan ensembles) and to a large extent the Sundanese musical idiom were used. The impact of jaipongan and degung kawih was great, although there were also popular music groups in West Java, like the group Bimbo that used Western instruments with a diatonic tuning. ${ }^{15}$ Also gamelan that combined the different Sundanese tuning systems (pélog, sorog, saléndro) were used for popular music.

Aside from jaipongan and degung kawih, there were many other musical experiments based on Sundanese musical instruments and idiom going on in West Java. Hellwig (1989) shows how the Sundanese immediately started experimenting with the genre jaipongan after it was created

15 For the Bimbo group see Jurriëns (2004:137-43). 
around 1978. Also, more traditional genres started to include music from outside Sunda. The ensemble consisting of two zithers and bamboo flute (kacapi-suling), led by the well-known Uking Sukri, was combined with a piano played by the famous jazz pianist Bubi Chen (MC Kedamaian 1989). However, this music did not achieve popular success and this may have been caused by the fact that the pianist stayed too close to the part of the small zither (kacapi rincik) and did not take enough freedom to improvise. In 1994 the kacapi-suling group of Radio (RRI) Bandung' ${ }^{16}$ recorded and broadcast Sundanese songs in a Japanese style; the songs were played in the high sorog tone system that is similar to a Japanese ryo tone system (Van Zanten 1989:114, 118). In these recordings the suling flute plays longer notes with a 'Japanese/ non-Sundanese' type of vibrato, the small zither imitates a Japanese type of playing by hitting the same note twice and especially in the beginning of the songs the zithers produce 'grace notes' before every main note. Also groups around the Bandung conservatory, the Patareman group (Deni Hermawan 2002), Zithermania, the very popular Sambasunda group and the ath-Thawaf group have been actively involved in musical experiments (Van Zanten 2007:7, 13-7; 2011:253-9).

\section{Travelling Musicians}

The Sundanese music scene has always included many different forms of music and many interpretations of the same music. This can partially be attributed to the fact that, in comparison with Central Java, the rulers in West Java had much less power to set performance standards. The Sundanese consider their cultural scene as varied: not every Sundanese would attach the same meaning to symbols and social phenomena. The context of Sundanese culture is becoming increasingly multi-cultural.

The different musics all need a proper social setting to be performed. However, musicians often cross the boundaries between the different musics: they can and do play several types of music. If we look at the musicians of popular music, it is for sure that quite a few of them 'travel' between different kinds of music; they often can also perform the less popular, 'traditional' types of music quite well. The boundaries between the different musics are certainly not prohibitive in Sunda, not only for most musicians, but also not for their audiences.

16 Consisting of Dede Suparman (kacapi indung), Rohayani (kacapi rincik 1 ) and Ade Suwandi (suling, kacapi rincik 2). 
There are several examples of musicians who started in the 'classical' tembang Sunda Cianjuran tradition, and then became also well known in popular music. For instance, the female singer Nénéng Fitri (born 1975), daughter of the well-known zither player Uking Sukri, won the prestigious DAMAS ${ }^{17} 1998$ singing contest for Cianjuran music. At the same time she also made several cassette recordings of the popular degung kawih music with Nano S., and once also entered - with some success - a singing contest for kroncong.

Yus Wiradiredja (born 1960) is a teacher of tembang Sunda Cianjuran music at the Bandung conservatory (STSI) and also winner of the DAMAS singing contest in 1984. He made several cassettes with recordings of popular music, including jaipongan. In 1997 he experimented with several other musicians of the Dasentra group with a recording of popular music, combining some Cianjuran 'classical' singing with a background of instrumental music (MC Saha eta? 1984; video Patareman 1997; see also article Deni Hermawan 2002). After his stay in the Netherlands and subsequent pilgrimage to Mecca in 1999, Yus Wiradiredja started the ath-Thawaf music group to make 'ethnic music with Islamic flavour' (musik etnik Islami). The music of the ath-Thawaf group is a fusion of several musical traditions and includes electronic instruments, but certain musical features, such as the frequent use of the sorog tone system and the use of instruments originating from West Java, make it specifically Sundanese (Van Zanten 2011:256-9).

Another example of someone travelling between several genres is Burhan Sukarma (born ca. 1945), the famous bamboo flute player in Cianjuran music of the 1970s and 1980s, who left for the USA. He was involved in the making of the 'fusion' music of the CD Sunda Afrika (1998; see Barendregt and Van Zanten 2002:74).

In November 2003 the music group Bimbo released a CD (and MC) Taqobbalallohu minnaa waminkum with qasidah (kasidah) music, using religious texts and topics. In the review in Kompas cyber media (16 November 2003) of this new album it was said that the Bimbo group from Bandung this time had a flavour of tembang Sunda. ${ }^{18}$ They know Sundanese music (karawitan Sunda) very well. According to this review, the Sundanese flavour in this album could be heard in the form of the

17 DAMAS stands for Daya Mahasiswa Sunda, the organisation of Sundanese students that is based in Bandung.

18 'Bimbo, 'Taqobbalallohu Minnaa Waminkum', http://www2.kompas.com/kompas -cetak/o311/16/hiburan /691751.htm (last accessed 18-5-2009). 
melody, and the vocal ornaments sung by Iin Parlina that reminded of the sinden style of singing. The reviewer remarked that the 'fresh and peaceful' (sejuk dan damai) Sundanese feeling was enforced by suling bamboo flute and drum playing, notably in the songs Marhaban and Sifat 20 .

Well-known vocalists like Tati Saleh (1944-2006) and Euis Komariah (1949-2011) were trained as all-round musicians at the music schools (KOKAR). ${ }^{19}$ The ease with which these musicians perform several types of music makes it sometimes difficult to determine the boundaries of the different kinds of music. Both Tati Saleh and Euis Komariah are known as performers of Cianjuran, jaipongan, degung kawih and many other types of popular music. Tati Saleh, Euis Komariah and Yus Wiradiredja are performers on the recordings to be analysed next.

\section{Recorded Songs for Musical Analysis}

The different performances of the recorded songs Bajing luncat (9 recordings, listed in Table 11.1) and Sorban palid (12 recordings, listed in Table 11.2) were used to look at some musical characteristics and the issue of what makes popular music 'Sundanese'. I shall present a musical transcription of one recording of each of the two songs. The recordings were used to analyse tone material, structural aspects of time and melody, and also performative aspects, such as instrumentation, some vocal qualities, absolute pitch and tempo. I want to know how the musical aspects differ in the analysed performances and how it changed in a 30-year time period. Therefore there are about 30 years between the first and the last recording of each song.

Each of the songs Bajing luncat and Sorban palid exists already for such a long time that during a period of at least 30 years there are many recordings available on mass distributed media: cassette tape, CD and VCD. The song Sorban palid is the oldest of the two songs and the composer is unknown. Bajing luncat was composed by Kosamanjaya in the first half of the 196os. The two songs share the characteristic that they use one of the Sundanese tone systems that may 'reasonably' be reproduced on instruments tuned according to the Western equidistant 12-tone tuning: pélog (Sorban palid) and sorog (Bajing luncat). From the available recordings in

19 KOKAR is an abbreviation of Konservatori Karawitan, conservatory of Indonesian music (and dance) that is now called SMKI, Sekolah Menengah Karawitan Sunda. 
this period I have chosen several types of performing ensembles and tried to cover the period from the 1970s until the beginning of the twenty-first century in order to get an overview of the different ways of performing these songs during that time period.

Almost none of the analysed recordings of Bajing luncat and Sorban palid could be classified as pop Sunda according to the definition of the 1989 workshop 'What is a regional pop song' because electronic instruments were used. Nevertheless, most producers indicated their albums as pop Sunda. It shows that the restrictive definition of pop Sunda may not be very useful. The 1989 workshop (rightly) saw the tone material used as one of the important criteria to decide whether a song was pop Sunda. However, are the Sundanese tone systems pélog and sorog played on electronic instruments no longer 'Sundanese'? Musicians will hear the differences, but I guess that for most Sundanese audiences it will sound 'Sundanese', be it in a different musical setting. Moreover Sundanese audiences have been used to similar phenomena in other types of music: it is possible to have, for instance, a Cianjuran sorog song accompanied by instruments that are tuned in saléndro; in this case the sorog intervals of the song are slightly adjusted to the saléndro tuning of the instruments (Cook 1993:75).

On the VCD Tembang kenangan pop Sunda (2002) Endang S. Taurina sings quite a few songs by Nano S., including the very successful degung kawih song Kalangkang, accompanied by electronic instruments and I assume most audiences will call this pop Sunda, like it is written on the cover. Also well-known 'classical' musicians, like Uking Sukri and Yus Wiradiredja, saw no problems in playing together with piano and electronic instruments on which the Sundanese tone systems may only be approximated, as I have pointed out above.

The singers on the analysed recordings were all women, except for S. Mansyur and Yus Wiradiredja (numbers 2 and 5 in Table 2). This is not because the selection was heavily biased, but it reflects the situation in West Java: in the twentieth century Sundanese popular and classical stages have become increasingly a female domain (Williams 1998:77) and live music has more and more been conceived of in gendered terms. Elsewhere I have stated that the Sundanese arts represent female aspects of human communication (see, for instance, Van Zanten 2008:48-9). These days Sundanese female singers are apparently better in 'casting a spell over us so that we see the real world in an enchanted form' (Gell 1999:163). 


\section{The Song Bajing Luncat between 1960 and 2002}

The song Bajing luncat was composed by Kosamanjaya ${ }^{20}$ in the first half of the 1960 s, and the song was meant to be played by Western-style bands (Jurriëns 2004:114; liner notes audio CD Detty Kurnia - Coyor panon 1993). However, it has also been adopted by other ensembles, something that has been common practice in West Java, as well as in other parts of the world. In all but one recording that I used for my analysis (see Table 11.1) the accompaniment of the song was with electric guitars, keyboard synthesizers, programmed drumming, drums, other Western instruments, and only now and then a Sundanese instrument, mostly a suling bamboo flute, was added for a short melodic phrase. Recording 4 is instrumental and played by a kacapi-suling ensemble, consisting entirely of Sundanese zithers and bamboo flute. For the transcription of Bajing luncat I used Upit Sarimanah's rendition. The transcription starts after the instrumental introduction of 41 seconds.

The two recordings of Bajing luncat by Upit Sarimanah ${ }^{21}$ and Tati Saleh on the MC Album nostalgia pop Sunda (1980?; with some re-issued recordings of the 1960s) are remarkable. Upit Sarimanah's recording was presumably made in the first half of the 196os. Here a trumpet playing with damper, and so producing the typical 'wow-wow' sound a few times, has been added to the electric instruments. The singing style of Upit Sarimanah, who also sang as pesinden (sinden, pasinden) in wayang golék theatre, is a mixture of Sundanese and Western styles. The many grace notes, and other singing ornaments, are a significant part of Sundanese singing; a grace note after the main note often leads to a sudden stop ('glottal stop') common in Sundanese singing.

As can be seen from the musical transcription, Upit Sarimanah ends her song on a high note, which does not happen in the older Sundanese styles. Tati Saleh ends with section D and her last phrase, ending on the first note of C (text in transcription '... pakait ati', although Tati Saleh uses another text) is also high: one octave higher than in the transcription.

20 Alias Kosoman Djaya, Koesmana Djaja, Kusmana Jaya, Kasaman Djaya.

${ }^{21}$ Upit Sarimanah (1928-1992) belonged with Titim Fatimah (1936-1995) to the first generation of singers of popular Sundanese music after independence. Posthumously they both received the Satya Lencana Kebudayaan award from the Indonesian government on 10 November 2002 (Hana Rohana S. 2002:64). Whereas in most publications 1936 is given as the year Titim Fatimah was born (see for instance, Ensiklopedi Sunda 2000:662), Endang Caturwati (2003/4:78-80) gives the year 1929 and also mentions that Titim Fatimah married six times, for the first time at the age of 13 in 1942 with Edi, a village secretary. 
Table 11.1. Analysed recordings of song Bajing luncat (by Kosamanjaya).

\begin{tabular}{|c|c|c|c|c|c|}
\hline $\begin{array}{l}\text { Vocalist and } \\
\text { source }\end{array}$ & $\begin{array}{l}\text { Date of } \\
\text { Recording* }\end{array}$ & $\begin{array}{l}\text { Notes about the } \\
\text { accompaniment }\end{array}$ & $\begin{array}{l}\text { Pitch }^{* * *} \\
\text { 1st and } \\
\text { 3rd note }\end{array}$ & $\begin{array}{l}\text { Tempo } \\
(\text { d)*** }\end{array}$ & $\begin{array}{l}\text { Total } \\
\text { duration } \\
\text { m:sec }\end{array}$ \\
\hline $\begin{array}{l}\text { 1. Upit } \\
\text { Sarimanah } \\
(1928-1992) \\
\text { MC Album } \\
\text { nostalgia pop } \\
\text { Sunda (1980?) }\end{array}$ & $1960-65$ & $\begin{array}{l}\text { Trumpet, other } \\
\text { Western } \\
\text { instruments, } \\
\text { electronic } \\
\text { instruments }\end{array}$ & $c / e b$ & $5^{6}$ & $3: 5^{2}$ \\
\hline $\begin{array}{l}\text { 2. Tati Saleh } \\
\text { (1944-2006) } \\
\text { MC Album } \\
\text { nostalgia pop } \\
\text { Sunda (1980?) }\end{array}$ & ca.1970 & $\begin{array}{l}\text { Electric guitars } \\
\text { and hammond } \\
\text { organ }\end{array}$ & $\mathrm{a} / \mathrm{c}$ & 50 & $3: 21$ \\
\hline $\begin{array}{l}\text { 3. Nining } \\
\text { Meida AS } \\
\text { MC Tibelat } \\
\text { (ca. 1988) and } \\
\text { identical Audio } \\
\text { CD Bubuy } \\
\text { bulan (1988) }\end{array}$ & 1987/1988 & $\begin{array}{l}\text { Electronic } \\
\text { instruments, } \\
\text { drums }\end{array}$ & $\mathrm{b} / \mathrm{d}$ & 47 & 4:03 \\
\hline $\begin{array}{l}\text { 4. Instrumental } \\
\text { CD Kacapi- } \\
\text { suling-Cinta } \\
(1992)\end{array}$ & 1992 & Kacapi-suling & $\mathrm{b} / \mathrm{d}$ & 54 & $7: 20$ \\
\hline $\begin{array}{l}\text { 5. Detty Kurnia } \\
\text { Audio CD } \\
\text { Detty Kurnia } \\
\text { - Coyor panon } \\
\text { (1993) }\end{array}$ & 1992 & $\begin{array}{l}\text { Suling (bamboo } \\
\text { flute), electronic } \\
\text { instruments, } \\
\text { drums }\end{array}$ & $\mathrm{d} / \mathrm{f}$ & $5^{2}$ & $4: 29$ \\
\hline $\begin{array}{l}\text { 6. Aty Surya } \\
\text { VCD Pop } \\
\text { Sunda } \\
\text { nostalgia } \\
\text { (ca. 200o) }\end{array}$ & 1999 & $\begin{array}{l}\text { Suling, keyboard } \\
\text { synthesizer and } \\
\text { other electronic } \\
\text { instruments }\end{array}$ & $\mathrm{a} / \mathrm{c}$ & $5^{2}$ & $4: 30$ \\
\hline $\begin{array}{l}\text { 7. Helvy } \\
\text { Maryand } \\
\text { VCD Sorban } \\
\text { palid disco } \\
\text { Sunda } \\
\text { (ca. 2000) }\end{array}$ & ca. 2000 & $\begin{array}{l}\text { Keyboard } \\
\text { synthesizer and } \\
\text { other electronic } \\
\text { instruments }\end{array}$ & $\mathrm{a} / \mathrm{c}$ & 60 & $4: 3^{2}$ \\
\hline
\end{tabular}


Table 11.1. (Cont.)

\begin{tabular}{|c|c|c|c|c|c|}
\hline $\begin{array}{l}\text { Vocalist and } \\
\text { source }\end{array}$ & $\begin{array}{l}\text { Date of } \\
\text { Recording* }\end{array}$ & $\begin{array}{l}\text { Notes about the } \\
\text { accompaniment }\end{array}$ & $\begin{array}{l}\text { Pitch** } \\
\text { 1st and } \\
\text { 3rd note }\end{array}$ & $\begin{array}{l}\text { Tempo } \\
(\text { d)*** }\end{array}$ & $\begin{array}{l}\text { Total } \\
\text { duration } \\
\text { m:sec }\end{array}$ \\
\hline $\begin{array}{l}\text { 8. Endang S. } \\
\text { Taurina } \\
\text { VCD Tembang } \\
\text { kenangan pop } \\
\text { Sunda (2002) }\end{array}$ & 2002 & $\begin{array}{l}\text { Suling, keyboard } \\
\text { synthesizer and } \\
\text { other electronic } \\
\text { instruments }\end{array}$ & $\mathrm{b} / \mathrm{d}$ & $5^{2}$ & $4: 26$ \\
\hline $\begin{array}{l}\text { 9. Unknown } \\
\text { VCD Mega } \\
\text { hits nostalgia } \\
\text { pop Sunda } 1 \\
\text { (ca. 2002) }\end{array}$ & ca. 2002 & $\begin{array}{l}\text { Angklung } \\
\text { (shaken } \\
\text { bamboos), } \\
\text { keyboard } \\
\text { synthesizer and } \\
\text { other electronic } \\
\text { instruments }\end{array}$ & $\mathrm{a} / \mathrm{c}$ & 59 & $3: 32$ \\
\hline
\end{tabular}

\footnotetext{
* Dates are mostly approximate, as clear information is missing on the volumes.

** Pitch measurements are approximate and rounded to the nearest Western semitone, also in the following table. In measuring the pitches I used my own ears, compared with the standard a of a tuning fork, and checked these measurements with a Korg Master Tune MT 1200. The 1st and 3rd tones are the ones on which the following italic syllables are sung: 'Ba-jing lun-cat ...' In Western terms the first note gives the 'minor key' note; so Upit Sarimanah's version is written in 'c - minor', with three flats, and Tati Saleh's version is in 'a - minor', without any accidentals (sharps and flats).

*** The number of beats per minute (that is, the number of crotchet notes per minute) is an average; most performers keep a fairly constant tempo.
}

The other six female singers stayed fairly close to this transcribed melody; however, they end with section E, and do not sing the 'non-Sundanese' section $\mathrm{F}$ that ends with a high note.

The tone material used in Bajing luncat is basically pentatonic and it could be considered to be the Sundanese sorog system, from high to low approximately: eb-d-c-ab-g-eb. In Western terminology this could be described as a part of the c-minor scale. The 'pélog notes' $\mathrm{f}$ in bars 10, and $27-28$, and b-flat in bars $28-29$ may be considered as ornamental notes. Also in the older Sundanese musics ornamental notes may be outside the pentatonic system. This is, for instance, the mixing of the pélog and sorog tone systems: in tembang Sunda Cianjuran music it is very common that the 'pélog note' (here b-flat) appears together with the 'sorog note' (here c); see further Cook (1993:59-63).

The song is sung in the order of sections A-B-C-D-E-F, indicated in the transcription, where section $\mathrm{E}$ is identical with $\mathrm{A}$, and section $\mathrm{D}$ is the same 


\section{Bajing Luncat}

Version IJpit Sarimanah

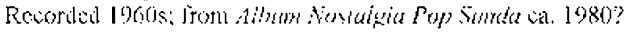
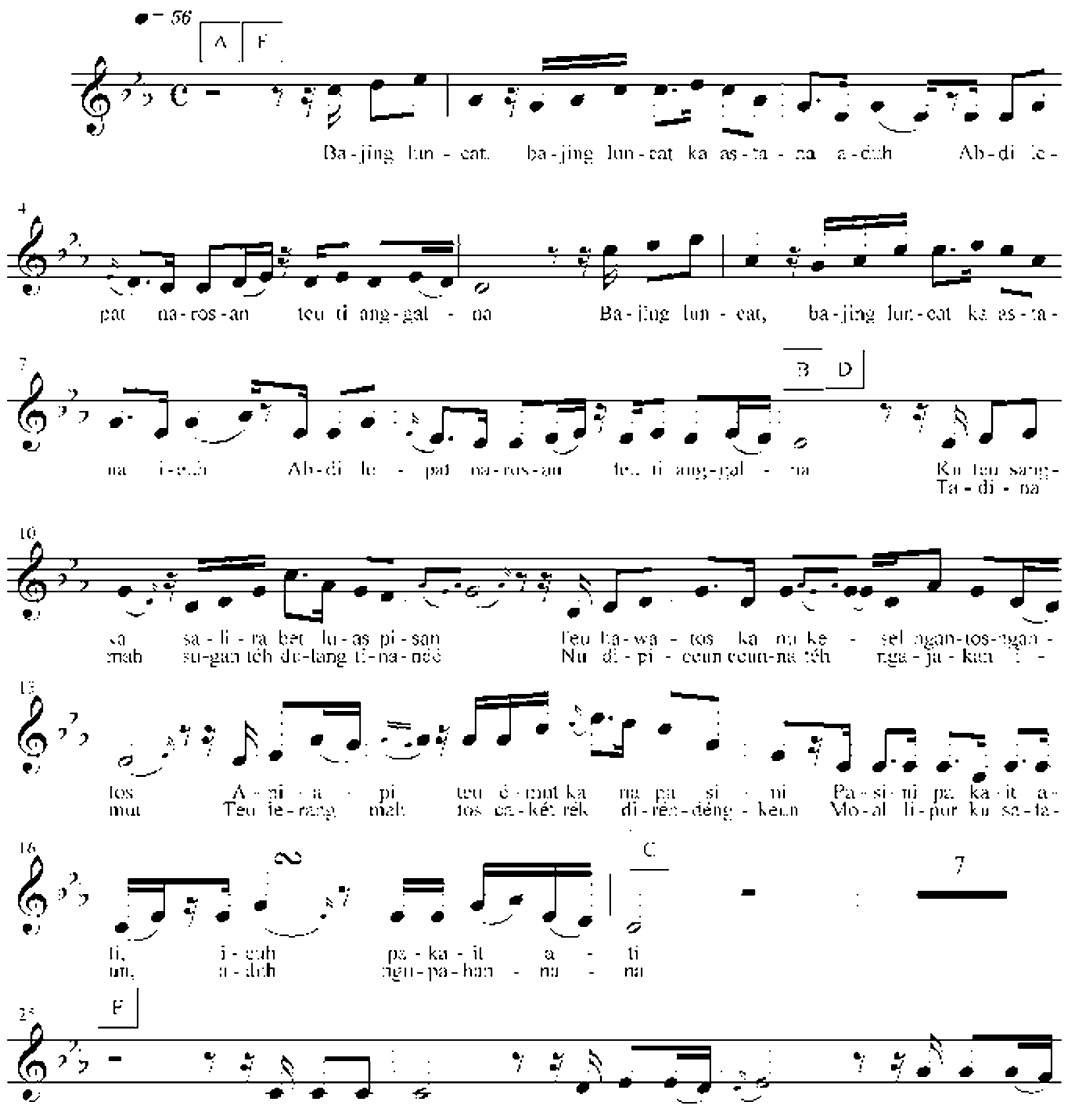

Ba- :ine un - cat. ba- jinş ur - cat.

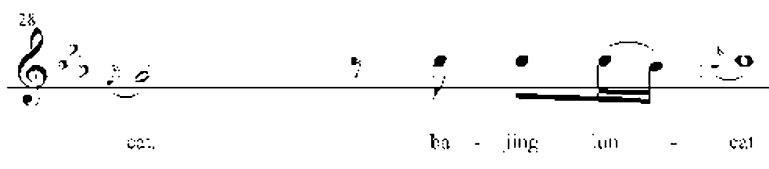

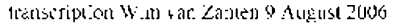

11.4. Transcription Bajing luncat by author. 
as $\mathrm{B}$, except for the words. The structure of the song is very regular; the sections $\mathrm{A}, \mathrm{B}, \mathrm{C}, \mathrm{D}$ and $\mathrm{E}$ each consist of 8 times a 4-beat bar;22 each section is again divided into two parts of 4 bars. The final section $\mathrm{F}$ is - without the last note - only 4 bars. This structure looks fairly 'Sundanese': the older metric music only uses '4-beat' time units that can be transcribed as 4-beat bars in Western notation, placing the structural 'gong notes' ending a musical phrase on the first beat.

The second rendering of Bajing luncat in this album is by Tati Saleh (1944-2006), a well-known singer of popular music. In this recording, presumably from around 1970, she is accompanied by Hawaiian-motives played by the electric guitar and a Hammond organ. Some accompanying patterns of the electric instruments remind us of the patterns played by the fast and high instruments in Sundanese music, like the kacapi rincik zither and saron metallophone.

The recording of Bajing luncat by Nining Meida around 1988 (MC Tibelat ca. 1988) is in instrumental accompaniment not very different from the recording by Tati Saleh. However, the singing style of Nining Meida with many inflections is closer to the style used in other Sundanese music.

Tempo is an important element in music. In the 9 versions there are differences in tempo, but these are not very striking. Nining Meida takes the slowest tempo $(\theta=$ ca. 47$)$ and Helvy Maryand takes the fastest (ca. 6o). For singers a slow tempo allows for more detailed ornamentation than a faster tempo, and especially Nining Meida used the slow tempo for many ornamentations. Nining Meida became famous with her interpretation of the song Kalangkang by Nano S. to the accompaniment of a gamelan degung ensemble (see Williams 1989:115-25), and which belongs to the pop Sunda repertoire. The instrumental kacapi-suling ensemble takes a tempo of 54 that is well in the range of most vocalists.

The variation in the total duration of the song is not just because of the different tempo taken, but also because the number and length of the instrumental sections, including introduction and ending, differs. For instance, the instrumental introduction is 41 seconds for Upit Sarimanah and 11 seconds for Nining Meida. Further, texts and music are added or repeated. The instrumental performance by the kacapi-suling ensemble (number 4) is an exception and is much longer than the other ones with a vocalist.

The absolute pitch of music is also relevant for Sundanese music (Van Zanten 1989:116-9). Detty Kurnia has the highest pitch (d). On average the pitch of the first note is around $c$ and the range is within 500 cents (or

${ }^{22}$ It could also be transcribed in 16 times a 2-beat bar, but that is less satisfying to me. 
5 semitones, from a to d). The data in Table 11.1 suggest that the pitch of the VCD versions, where the accompaniment is mainly a keyboard synthesizer, are more standardized than in the other recordings. The VCD renderings by Aty Surya, Helvy Maryand and Unknown are the same as Tati Saleh's: in Western terms in a-minor, which is music-technically the simplest key, without sharps or flats (hence no black keys on the keyboard are used). This standardization will be confirmed by the analysis of Sorban palid, and there I shall discuss the matter in more detail.

Detty Kurnia's recording of Bajing luncat includes a section with Sundanese bamboo flute (suling) playing, which applies typical Sundanese flute phrases. Pictures of a suling player also appear on the VCD recording by Endang S. Taurina: a real suling sound is heard, although the music is not synchronous with the movements. On the VCD with singer Aty Surya a suling player is seen and the sound is synchronous with the movements. Only the VCD with singer Helvy Maryand does not have any sound of a suling or other Sundanese instrument; it is just keyboard synthesizer and other electronic instruments for the accompaniment.

On the VCDs the information about the performers and their instruments is unfortunately very meagre. On six covers of the eight different volumes with recordings of Bajing luncat the type of music is called pop Sunda and once it is called disco Sunda. In the English liner notes of Detty Kurnia's CD it says: 'This album is a hybrid of many Sundanese musical styles such as Degung, Jaipongan, Calung, Pop Sunda and Kecapi Suling'. The CD of the instrumental kacapi-suling ensemble speaks of 'original Sundanese music'; only in this recording there are no electronic instruments. Bajing luncat is a song that belongs to the popular music repertoire of West Java, however, according to the contributions in Subagio (1989) most of these nine renderings would not be classified as pop Sunda.

The seven female singers do not differ very much in the text used for Bajing luncat, but several times part 3 of the text below was not used. The given text is the one as sung by Upit Sarimanah and also, with some different words, by Helvy Maryand and Endang S. Taurina.

\section{Text Bajing luncat}

1. Bajing luncat $(2 x)$ ka astana aduh/ieuh

Abdi lepat narosan teu $t i$ anggalna

2. Ku teu sangka salira bet luas pisan
The squirrel jumps into the graveyard, oh!

I was wrong not to ask him earlier to marry me (two lines repeated)

Because I did not guess and never feared this ending 
Teu hawatos ka nu kesel 23 ngantos-ngantos Api-api teu émut ka na pasini Pasini pakait ati ieuh pakait ati

3. Tadina mah sugan téh dulang tinandé

Nu dipiceun (ceunna) téh ngajakan imut

Teu terang mah tos cakét rék diréndéngkeun

Moal lipur ku sataun, aduh ngupahannana
I showed no compassion with him who was bored by waiting As if he did not remember the agreement The agreement between hearts, yes, between hearts

Maybe I should earlier have given in to all his wishes The one who was jilted was asking for a smile It did not happen, that those, who were already close, also got married I have not calmed down in a year, oh, his comforting caresses!

Although Detty Kurnia also uses almost exactly the above text, the liner notes of Detty Kurnia - Coyor panon (1993) explain the meaning of the song thus: '[T] his song is about a superstitious young girl, who, when she sees a bat [sic] flying into a graveyard, thinks it is a bad omen. She is reassuring herself.' This seems an interpretation that is only partially correct, as the text is rather about the loss of the beloved one, associated with the squirrel, who 'jumps into the graveyard', that is, disappears. Now that her beloved one has left her for another one, the woman regrets that she did not give in to his wishes, including his wish to make love to her. A sad text set to hot music and images.

Bajing luncat (or bajing loncat), the jumping squirrel, is also the name for a thief who operates on lorries, trains or buses. ${ }^{24}$ They jump on lorries when these slow down, or when there is a traffic jam, and steal some of the contents. ${ }^{25}$

From the analysis it becomes clear that the way of performing changed over time. Around the 1960s-1970s the style of performing included many

23 Tati Saleh and Detty Kurnia sing kersa, 'want', 'willing to do (something)'. In the lyrics presented on the Internet, most places, including the ones that give Detty Kurnia's text, use the word kesel (checked 12-5-2009).

24 Bajingan is a pickpocket, thief, crook, gangster in Indonesian and Sundanese.

25 See, for instance, the report in Kompas cyber media, 23-04-2009, 'Awas, bajing loncat beraksi', http://www.kompas.com/read/xml/2009/04/23/12221395/awas.bajing.loncat. beraksi (last accessed 18-5-2009). This meaning of Bajing luncat is referred to in the images of the version sung by Endang S. Taurina on the VCD Tembang kenangan pop Sunda (2002), where a young man tries to steal the purse of another man who is walking with his girl friend. Bajing luncat is also used to indicate politicians, who are corrupt, enrich themselves and stay in office forever; see http://www.hamline.edu/apakabar/basisdata/ 2002/01/12/0004.html (last accessed 27-11-2009). 
Western aspects, like a high final note by the singer (Upit Sarimanah, Tati Saleh), trumpets and Hammond organs for accompaniment and musical phrases from blues, Hawaiian guitars and rock-'n-roll. In the later recordings the addition of the Sundanese suling to the electronic instruments is remarkable. The sound of the suling, and also the sound of other Sundanese instruments like the calung, kendang, and kacapi, still forms an essential part of most of these recordings.

\section{The Song Sorban Palid between 1970 and 2002}

The song Sorban palid is older than Bajing luncat and its composer is not known. In the recordings there are - on the whole - less musical ornamentations than in Bajing luncat and all ornamentations stay within the Sundanese tone system (pélog). This could be, because Sorban palid is from a more distant past than Bajing luncat and the characteristic of keeping the ornaments within the used tone system has been preserved. ${ }^{26}$ Further, in contrast to Bajing luncat, the song Sorban palid has a section that is used for one-part chorus singing in performances 2, 7 and 9-12.

In the analysed recordings listed in Table 11.2 it may be seen that there is much more variation in accompaniment (including gamelan ${ }^{27}$ and kacapi zither), tempo and total duration than in the discussed recordings of the song Bajing luncat. The tempo of Detty Kurnia is remarkably fast, in the first section her tempo is twice the one taken by Titim Fatimah. Titim Fatimah makes a clear tempo difference between the first part (46) and the second part (52) that starts with the words: Kaso pondok, kaso panjang ... (see transcription). In Titim Fatimah's version the first part of the singing is close to a rubato style, without a strict beat. In the version by Nining Meida chorus singing and solo singing alternate in the second part. The total duration of the song varies also between the different performances, because more or less verses are sung. The duration of the vocal versions of Sorban palid varies more than the versions of Bajing luncat.

The tone material used in Sorban palid is pentatonic and it could be considered to be the Sundanese pélog tone system, from high to low approximately: f-e-c-bb-a-f. In Western terminology this could be

26 This phenomenon occurs in Cianjuran singing: performers in the beginning of the twentieth century used ornaments that stayed more than nowadays within the used tone system (as given on the kacapi zither), although occasionally using notes from one of the other Sundanese tone systems: pélog, sorog and saléndro.

27 It is not clear from the recordings and the given information what gamelan instruments are exactly used in items 1, 3, 5 and 7 of Table 11.2. 
Table 11.2. Analysed recordings of song Sorban palid (composer unknown).

\begin{tabular}{|c|c|c|c|c|c|}
\hline $\begin{array}{l}\text { Vocalist and } \\
\text { source }\end{array}$ & $\begin{array}{l}\text { Date of } \\
\text { recording }\end{array}$ & $\begin{array}{l}\text { Notes about the } \\
\text { accompaniment }\end{array}$ & $\begin{array}{l}\text { Pitches } \\
\text { first } \\
\text { note * }\end{array}$ & $\begin{array}{l}\text { Tempo } \\
(\text { d)** }\end{array}$ & $\begin{array}{l}\text { Total } \\
\text { durat } \\
\text { m:sec }\end{array}$ \\
\hline $\begin{array}{l}\text { 1. Titim Fatimah } \\
(1936-1995) \\
\text { MC Titim } \\
\text { Fatimah } 1 \text { (1970s) }\end{array}$ & $1970-75$ & $\begin{array}{l}\text { Gamelan; with } \\
\text { gambang, rebab }\end{array}$ & $a b$ & $46\left[5^{2}\right]$ & $6: 35$ \\
\hline $\begin{array}{l}\text { 2. Mansyur S. } \\
\text { MC Asa can lami } \\
\text { (ca. 1980) }\end{array}$ & ca. 1980 & $\begin{array}{l}\text { Suling, saron } \\
\text { metallophone, } \\
\text { electronic } \\
\text { instruments and } \\
\text { drums }\end{array}$ & f & 50 & 5:10 \\
\hline $\begin{array}{l}\text { 3. Elis Wizaksmi } \\
\text { MC Peuting nu } \\
\text { urang (ca. 1980) }\end{array}$ & ca. 1980 & $\begin{array}{l}\text { Kacapi siter, } \\
\text { rebab, suling } \\
\text { with gamelan }\end{array}$ & a & $5^{2}$ & $7: 30$ \\
\hline $\begin{array}{l}\text { 4. Imas Permas } \\
\text { MC Reuntas } \\
\text { harepan }(1980)\end{array}$ & 1980 & $\begin{array}{l}\text { Gamelan degung } \\
\text { (with suling) }\end{array}$ & $a b$ & 62 & $5: 02$ \\
\hline $\begin{array}{l}\text { 5. Euis Komariah } \\
\text { and Yus } \\
\text { Wiradiredja } \\
\text { Audio CD The } \\
\text { sound of Sunda } \\
(1990)\end{array}$ & 1990 & $\begin{array}{l}\text { Kacapi siter, } \\
\text { suling, gamelan } \\
\text { and tuned } \\
\text { Sundanese } \\
\text { drums }\end{array}$ & g & 54 & $5: 26$ \\
\hline $\begin{array}{l}\text { 6. Instrumental } \\
\text { MC The best } \\
\text { sound of } \\
\text { kacapi- suling } \\
(2004)\end{array}$ & 1992 & Kacapi-suling & g & 54 & $6: 20$ \\
\hline $\begin{array}{l}\text { 7. Detty Kurnia } \\
\text { Audio CD Detty } \\
\text { Kurnia-Dari } \\
\text { Sunda (1995) }\end{array}$ & 1995 & $\begin{array}{l}\text { Gamelan, } \\
\text { gambang } \\
\text { xylophone, } \\
\text { electronic } \\
\text { instruments }\end{array}$ & $\mathrm{f}$ & 92 & $5: 27$ \\
\hline $\begin{array}{l}\text { 8. Instrumental } \\
\text { MC Tibelat } \\
\text { (ca. 1988) }\end{array}$ & $1996 ?$ & $\begin{array}{l}\text { Kacapi siter, } \\
\text { suling, rebab, } \\
\text { kendang drum }\end{array}$ & $a b$ & 54 & $3: 5^{2}$ \\
\hline
\end{tabular}

(Continued) 
Table 11.2. (Cont.)

\begin{tabular}{|c|c|c|c|c|c|}
\hline $\begin{array}{l}\text { Vocalist and } \\
\text { source }\end{array}$ & $\begin{array}{l}\text { Date of } \\
\text { recording }\end{array}$ & $\begin{array}{l}\text { Notes about the } \\
\text { accompaniment }\end{array}$ & $\begin{array}{l}\text { Pitches } \\
\text { first } \\
\text { note * }\end{array}$ & $\begin{array}{l}\text { Tempo } \\
(d) * *\end{array}$ & $\begin{array}{l}\text { Total } \\
\text { duration } \\
\text { m:sec }\end{array}$ \\
\hline $\begin{array}{l}\text { 9. Helvy Maryand } \\
\text { VCD Sorban } \\
\text { palid disco } \\
\text { Sunda (ca. 200o) }\end{array}$ & ca 2000 & $\begin{array}{l}\text { Keyboard } \\
\text { synthesizer }\end{array}$ & $\mathrm{f}$ & 62 & $5: 03$ \\
\hline $\begin{array}{l}\text { 10. Nining Meida } \\
\text { VCD } \\
\text { Kalangkang } \\
\text { (ca. 200o) and } \\
\text { identical on } \\
\text { VCD Kawah } \\
\text { putih } \\
\text { (ca. 200o) }\end{array}$ & ca. 2000 & $\begin{array}{l}\text { Keyboard } \\
\text { synthesizer }\end{array}$ & f & 55 & $4: 38$ \\
\hline $\begin{array}{l}\text { 11. Irma } \\
\text { VCD Pop Sunda } \\
\text { nostalgia } \\
\text { (ca. 200o) }\end{array}$ & 2002 & $\begin{array}{l}\text { Suling, keyboard } \\
\text { synthesizer }\end{array}$ & $\mathrm{f}$ & $5^{6}$ & $5: 28$ \\
\hline $\begin{array}{l}\text { 12. Unknown } \\
\text { VCD Mega hits } \\
\text { nostalgia pop } \\
\text { Sunda } 2 \\
\text { (ca. 2002) }\end{array}$ & ca. 2002 & $\begin{array}{l}\text { Keyboard } \\
\text { synthesizer }\end{array}$ & $\mathrm{f}$ & 64 & $4: 21$ \\
\hline
\end{tabular}

\footnotetext{
* This note is also the final note. In Western terms the first note presents the 'major key' note; for the transcribed version of Nining Meida this is f-major.

** Titim Fatimah sings the second part [in these brackets], starting with 'Kaso pondok, kaso panjang...' slightly faster the first part. This is not the case with the transcribed version of Nining Meida and the other versions.
}

described as a part of the f-major scale. In the transcribed version of Nining Meida, there are no notes outside this pélog tone system. The transcription starts after the short instrumental beginning.

It is remarkable that the four VCD versions all start at the same pitch (f) and the other recordings show a variety of starting notes. This confirms what we have remarked about the song Bajing luncat: the tuning of a gamelan cannot be changed easily and the different gamelan ensembles are tuned to different pitches (up to 4 semitones difference). The zithers can easily be tuned to another pitch, according to the wishes of the performers. This is different for the keyboard synthesizers that are tuned to the Western equidistant 12-tone system with a fairly narrow range of the note $\mathrm{A}$ 
(between 400 and 404 Hertz). This Western equal-tempered tone system allows for transposing the song up or down. However, a transposition by one semitone up or down would add technical difficulties for the playing (adding seven sharps or seven flats). From a music-technical perspective, transposing two semitones up or down would make a better option; however, this is apparently not done on these VCD renderings of Sorban palid. ${ }^{28}$

The musical structure of the first part of Sorban palid is - like Bajing luncat - according to most Sundanese metric songs: 4-beat 'bars' and a section of 8 'bars' (that is repeated) or $8 \times 4=32$ beats. However, the second

\section{Sorban Palid}

Version Vining Meida

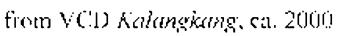
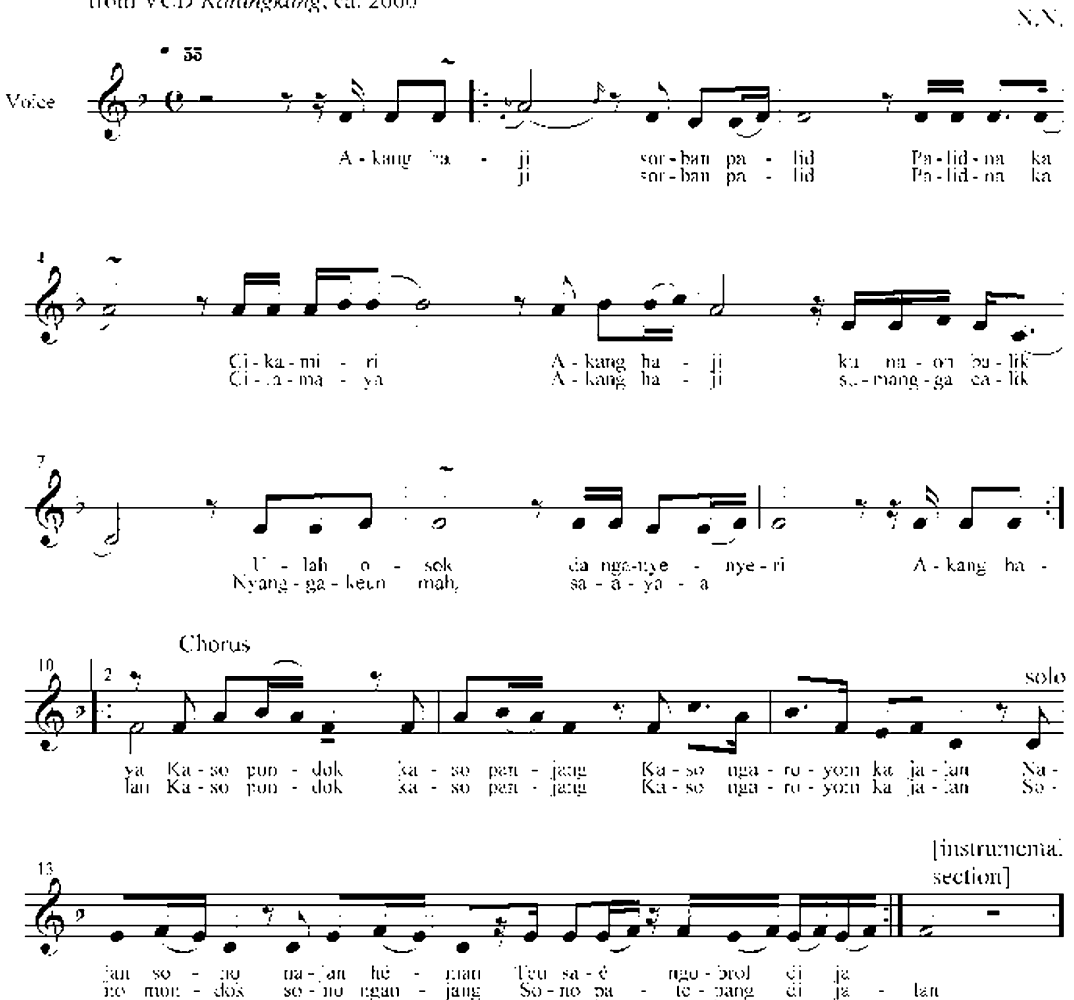

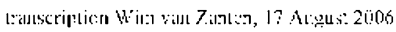

11.5. Transcription Bajing luncat by author.

28 In contrast: this was done in the VDC versions of Bajing luncat, where the pitch of Endang S. Taurina was 2 semitones higher that the other VCD versions (b against a). 
part consists of 5 times a 4-beat 'bar' that is repeated (see transcription). An uneven number of 4-beat 'bars' is less common in older Sundanese music; and if so, such section is mostly repeated, like it is in Sorban palid.

The presented text of Sorban palid is the one used by Nining Meida and also by Helvy Maryand. The third and fourth verses are very well-known texts in sisindiran form, that is, sound association between the first two and the last two lines, where the first two lines are the 'rind' and the last two lines are the 'content' of the verse (see further Van Zanten 1989:6870). This sisindiran text may also be used in other songs. Similarly, in these recordings of Sorban palid some singers used a different text in sisindiran form.

Text of Sorban palid

Solo:

Akang haji Sorban palid Palidna ka Cikamiri

Akang haji ku naon balik Ulah osok da nganyenyeri

Brother haji, the head cloth floats away It is floating to Cikamiri Brother haji, why do you go home? Don't do that, as it will hurt [me].

Akang haji Sorban palid Palidna ka Cilamaya Brother haji, the head cloth floats away It is floating to Cilamaya Akang haji sumangga calik Nyanggakeun mah saaya-aya Please (elder) brother haji, sit down Take whatever we have

\section{Chorus:}

Kaso pondok kaso panjang Kaso ngaroyom $^{29}$ ka jalan Najan sono najan héman Teu saé ngobrol dijalan

Kaso pondok kaso panjang Kaso ngaroyom ka jalan Sono mondok sono nganjang Sono patepang dijalan

Short grass and long grass The grass bends over the road When full of strong desires and tender care It is not good to talk on the road

Short grass and long grass The grass bends over the road [Those with] strong desires stay and pay a visit [Those with] strong desires meet at the road.

The different versions of other popular songs with a record history of 40 years or more, like Es Lilin, Bubuy Bulan and Mojang Priangan, show similar characteristics and variations as described above for Banjing luncat and Sorban palid. Several of these songs are still popular and video versions may be found on YouTube, although not always with the correct

29 Sometimes ngaroyong is used instead of ngaroyom: 'The grass is carried by several people together on the road.' 
information. Es Lilin seems to be most widely available, for instance in jaipong, angklung and dangdut versions, a kroncong version by Hetty Koes Endang, a Malaysian version by Siti Nurhaliza and in an instrumental versions, for instance by the Kwartet Panakawan that includes a piano.

\section{Conclusion}

In this essay I have concentrated on some musical aspects of popular music in West Java between 1960 and the beginning of the twenty-first century. It cannot be denied that texts in the Sundanese language and social context play an important role in popular music, however, the musical aspects are also very important for to make it sound 'Sundanese' or not.

As most performers of popular music in West Java are also able to perform other types of Sundanese music, this affects the sound of the popular music. I have argued that the present-day popular songs still have much Sundanese sound and structure, even when performed on electronic instruments. Therefore audiences may not experience pop Sunda, as it has been defined by the 1989 Bandung workshop, in a very different way from other types of popular music in West Java. It seems better to use the term pop Sunda in a much wider meaning than defined in 1989. The use of keyboard synthesizers has a standardising effect on the pitch of the popular songs. Nevertheless the musicians are still able to let their audiences see the world in an enchanted form, musically coloured 'Sundanese' by the use of Sundanese tone systems, mostly 8 and 16-beat musical phrases, singing ornaments, musical patterns, and the melancholic sound of the suling.

I consider my musical analysis only a modest start; this research still awaits more thorough investigation: what are the technologies that Sundanese musicians have been applying to let us see the world in an enchanted form? For instance, in most popular musics the vocal part is very prominent. However, as yet we do not know very much about the voice qualities, appreciated by the different audiences. Which voice qualities of Titim Fatimah or Nining Meida are appreciated by the listeners? It would be very interesting to know more about the perception of musical and vocal qualities in popular music. In tembang Sunda Cianjuran music voices are described in a number of ways, like sweet, vigorous, modest, pleasing, hoarse and 'not clear' (Van Zanten 1989:160, 180). A careful study of the musical aspects of popular music, for instance with perception experiments, would give the opportunity to contribute to the discussion on Sundanese aesthetics in a globalising world. 


\section{References}

Affandie, H.R. Ading [RAF]. 'Tanggung jawab seniman pada perkembangan budaya dan pembinaan jiwa masyarakatnya', in: Gunawan Subagio (ed.), Apa itu lagu pop daerah, pp. 22-9. Bandung: Citra Aditya Bakti, 1989 .

Barendregt, B. and W. van Zanten. 'Popular music in Indonesia since 1998, in particular fusion, indie and Islamic music on video compact discs and the internet', Yearbook for Traditional Music 34:67-113, 2002.

Beraadslagingen. 'Beraadslagingen van de ontwikkelingsmogelijkheden van de muziek op Java' [Discussions about the possibilities to develop the music in Java], Djåwå 1:284-302. [Report of the meeting on Sunday 19 June 1921 of the Congress of the Java Institute in Bandung.], 1921.

Boonzajer Flaes, R. Bewogen koper: Van koloniale kapel tot wereldblaasorkest. Amsterdam: De Balie; The Hague: Novib, 1993.

Caturwati, E. 'Titim Fatimah: Sinden ternama di Jawa Barat', Jurnal Seni Pertunjukan Indonesia 12:73-89, 2003/4.

Cook, S. 'Parallel versions of tembang Sunda melodies in different tunings', in Wim van Zanten (ed.), Oideion: The performing arts world-wide, pp. 55-84. Leiden: Centre of Non-Western Studies, 1993.

Ensiklopedi Sunda. Ensiklopedi Sunda: Alam, manusia, dan budaya, termasuk budaya Cirebon dan Betawi. Jakarta: Pustaka Jaya, 2000.

Gell, A. 'The technology of enchantment and the enchantment of technology', in: Alfred Gell, The art of anthropology, edited by E. Hirsch, pp. 159-86. London and New Brunswick, NJ: The Athlone Press, 1999.

Hana Rohana S. (HRS). 'Upit Sarimanah dina panineungan ngangkat harkat derajat sinden', Mangle 1892 (19-25 December):64-6, 2002.

Harnish, D. 'Teletubbies in paradise: Tourism, Indonesianisation and modernisation in Balinese music', Yearbook for Traditional Music 37:103-23, 2005.

Heins, E.L. 'Kroncong and tanjidor: Two cases of urban folk music in Jakarta', Asian Music 7-1: 20-32, 1975 .

_- 'J.S. Brandts Buijs (1879-1939)', in Biografisch woordenboekvan Nederland, URL:http:// www.inghist.nl/Onderzoek/Projecten/BWN/lemmata/bwn5/brandtsbuijs [13-03-2008] (last accessed 15-11-2009; original version included in Biografisch woordenboek van Nederland 5, Den Haag 2002), 2008.

Hellwig, J.C. Sundanese popular culture alive!!! A documentary about jaipongan and other performing arts of Sunda. Amsterdam: Hellwig Productions. [Video film VHS 48 minutes; camera: F. Krom.], 1989.

— . 'Jaipongan: The making of a new tradition', in: B. Arps, (ed.), Performance in Java and Bali: Studies of narrative, theatre, music, and dance, pp. 47-58. London: School of Oriental and African Studies, 1993.

Hermawan, D. 'Kreativitas Mang Koko dan masa kini dalam karawitan Sunda', Panggung: Jurnal seni STSI Bandung 5:1-25, 1996.

—. 'Dialektika musik Islam; Musik Islami: keserasian antara tema verbal dengan ekspresi musikal', Panggung:Jurnal seni STSI Bandung 17:68-82, 2000.

—_. 'Musik Sunda Patareman: Konsep garapan, proses, perwujudan, dan perkembangannya', Panggung: Jurnal seni STSI Bandung 23:26-43, 2002.

Jurriëns, E. Cultural travel and migrancy: The artistic representation of globalization in the electronic media of West Java. Leiden: KITLV Press. [Verhandelingen 216.], 2004.

Mak van Dijk, H. De oostenwind waait naar het westen: Indische componisten, Indische composities, 1898-1945. Including CD and with a contribution by Frans Schreuder. Leiden: KITLV Uitgeverij, 2007.

Proceedings. Proceedings international conference on the safeguarding of tangible and intangible cultural heritage: Towards an integrated approach, Nara, Japan, 20-23 October 2004. Paris: UNESCO, http://unesdoc.unesco.org/images/o014/001470/147097M .pdf (last accessed 19-5-2009), 2004. 
Rukmiati, T. and R. Iyus. 'Jaipongan "Oray welang” karya Gugum Gumbira Tirasonjaya: Sekilas tentang hubungannya dengan tari tradisi', Panggung: Jurnal seni ASTI Bandung 7-2:19-21, 1994.

Ruswandi, T. 'Wawasan seni Koko Koswara dalam perkembangan karawitan Sunda', in: A.S. Nalan and A.R. Sarjono (eds), Catatan Seni, pp. 45-58. Bandung: STSI Press, 1996.

Stockmann, E. 'The International Folk Music Council/International Council for Traditional Music - forty years', Yearbook for Traditional Music 20:1-18, 1988.

Subagio, G. (ed.). Apa itu lagu pop daerah. Bandung: Citra Aditya Bakti, 1989.

Suratno, N. [Nano S.]. 'Getar-getar wanda anyar desah-desah pop daerah', in: G. Subagio (ed.), Apa itu lagu pop daerah, pp. 22-9. Bandung: Citra Aditya Bakti, 1989.

Tiarsa R., Us, E.D. Iskandar, M. Mintarsih and S. Pupung. 'Rumusan lokakarya lagu pop daerah TVRI Station Bandung', in: G. Subagio (ed.), Apa itu lagu pop daerah, pp. 62-5. Bandung: Citra Aditya Bakti, 1989.

Wibisana, W. 'Penelusuran kecil terhadap munculnya musik pop daerah', in: G. Subagio (ed.), Apa itu lagu pop daerah, pp. 31-40. Bandung: Citra Aditya Bakti, 1989.

Williams, S. 'Current developments in Sundanese popular music', Asian Music 21-1:105-36, 1989 .

_. 'Constructing gender in Sundanese music', Yearbook for Traditional Music 30:74-84, 1998.

Zanten, W. Van. Sundanese music in the Cianjuaran style: Anthropological and musicological aspects of tembang Sunda. Dordrecht, Providence: Foris. [With demonstration tape; KITLV Verhandelingen 140.], 1989.

- 'Sung epic narrative and lyrical songs: Carita pantun and tembang Sunda', in: B. Arps (ed.), Performance in Java and Bali: Studies of narrative, theatre, music and dance, pp. 144-61. London: School of Oriental and African Studies, 1993.

- 'Constructing new terminology for intangible cultural heritage', Museum International 221/222:36-44, 2004.

- 'God is not only in the holy scriptures, but also in the arts: Music, cultural policies and Islam in West Java', Conference 'Music in the world of Islam', Assilah, 13-18 August 2007, http://www.mcm.asso.fr/site02/music-w-islam/articles/van_Zanten-2007. pdf (last accessed 11-5-2009), 2007.

- 'The marriage relationship between player and kacapi zither in West Java', Ethnomusicology Forum 17:41-65, 2008.

— . 'The discourse on Islam and music in West Java, with emphasis on the music group, ath-Thawaf', in: D. Harnish and A. Rasmussen (eds), Divine Inspirations: Music and Islam in Indonesia, pp. 241-66. Oxford/New York: Oxford University Press, 2011.

\section{Audio visual materials}

Album nostalgia pop Sunda. Cassette tape. Bandung: MC Records/ Brata Records. Female singers: Upit Sarimanah, Titim Fatimah, Tati Saleh, Euis Komariah. [This album includes recordings that were most probably made in the 196os, like the recordings of Bajing luncat by Upit Sarimanah.], 1980?

Asa can lami. Cassette tape. Jakarta: Hayam Wuruk Record. Singers: Mansyur S. and Yani, 1980 ?

Bubuy bulan. Audio CD. Wishnu Record, 1988.

Detty Kurnia. Coyor panon. Audio CD with 'world music' recorded in 1992. London: Timbuktu Records FLTCD 519, 1993.

- Dari Sunda. Audio CD. London: Riverboat Records; Tokyo: Wave, TUGCD1o11. Female singer Detty Kurnia accompanied by Koko Wahyudin (kendang), Hideo Inoura, Makoto Kubota and his group, Sandii and the Sunsetz, 1995.

Kacapi-suling - Cinta. Audio CD [earlier released as cassette tape]. Kacapi-suling group Gelik, led by Ade Suwandi: Endang Sukandar (suling); Dede Suparman (kacapi indung); Yudi (kacapi rincik 1); Yani (kacapi rincik 2). Jakarta: Karaton CDK-014, 1992. 
Kalangkang. VCD Pop Sunda Getek's Group. Jakarta: Wishnu Records. Vocalists: Nining Meida and Adang Cengos, 200o?

Kawah putih. VCD, probably pirate copy of original VCDs. Female vocalist: Nining Meira, 2000 ?

Kedamaian. Cassette tape of kacapi-suling music (two zithers and bamboo flute) with (acoustic) piano. Performers: Bubi Chen (piano), Uking Sukri (kacapi indung), Dede Suparman (kacapi rincik), Endang Sukandar (suling). Bandung: Hidayat, \#8902, 1989.

Kembang tanjung panineungan. Cassette tape. Bandung: Hidayat, no. S-1052. Singer: Ida Rosida; kacapi zither: Maman S. Songs by Koko Koswara, 1984.

Mega hits nostalgia pop Sunda 1.VCD Warung Pojok. [Suara Citra Sejati?], 2002?

Mega hits nostalgia pop Sunda 2. VCD Sorban palid karaoke. Suara Citra Sejati, 2002?

Patareman.VCD/video. Bandung: Dasentra, 1997.

Peuting nu urang. Cassette tape. Kawih Sunda group Tunjung Balebat: Elis Wizaksmi, vocalist; Burhan Sukarma (suling); Maman (kacapi 1); Atang Warsita (kacapi 2); Ahmad Kusnadi (goong); Uloh Abdullah (rebab). Jakarta: Gita Record, 1980?

Pop Sunda nostalgia. Video CD with singers Aty Surya, Irma and Rini Odoy. Akurama Records ARVCD - 028, 2000.

Reuntas harepan. Cassette tape. Gamelan degung group Gapura Bandung, led by Koestyara, with Imas Permas, vocalist; O. Burhan Sukarma (suling); Bao Sonjaya (kendang). Dian Records, 1980.

Saha eta? Cassette tape 'Kawih Sunda kacapian: Garapan seni Dasentra', group led by Ubun Kubarsah R., with singer Ida Rosida Koswara and singer/composer Yus Wiradiredja. Bandung: Suara Parahiangan (SP) Records, 1984.

Shalawat Nabi al-Imam: Kawih pupujian Sund. Cassette tape with songs composed by Koko Koswara (1915-1985) and most song texts by Ading Affandi (R.A.F.). Group Ganda Mekar, led by Tatang Benyamin Koswara. Bandung, 1995 .

Sorban palid disco Sunda. VCD with female vocalist Helvy Maryand. MCP (MGo26), 2000 ?.

Sunda Africa. Audio CD 'Sunda Africa: No risk no fun (Bamboo flute, harp \& drums)' with Burhan [Sukarma], Ismet Ruchimat, Agus Supriawan, Dodong, Vidal Paz. Jakarta: Cakrawala Musik Nusantara, 1998.

Taqobbalallohu minnaa waminkum. Audio CD by musical group Bimbo: Samsudin, Acil Darmawan, Jaka Purnama (leader), and Iin Parlina. Released in November 2003. Sony Music, 2003.

Tembang kenangan pop Sunda. VCD 'Pop Sunda'. Getek's group, led by Yan Achimsa, and with singer Endang S. Taurina. MCP: MG-044, 2002.

The best sound of kacapi-suling. Cassette tape with music groups Gelik, Gentra Pasundan and Kancana Sari. Jakarta: Gema Nada Pertiwi/ Keraton KR-o68, 2004.

The sound of Sunda. Audio CD with Euis Komariah and Yus Wiradiredja (vocalists), accompanied by the Jugala Orchestra and the Pateraman Dasentra Group. London: Ace Records CDORB 06o, 1990.

Tibelat. Cassette tape 'Pop Sunda'. Getek's group with singers Nining Meida AS and Barman Sahyana. Whisnu Record, 1988?.

Titim Fatimah 1. Cassette tape 'The golden album of Titim Fatimah, volume 1'. Gamelan group 'Cahya Sumirat' led by Titim Fatimah: Titim Fatimah, vocalist and Inen Saputra (lurah sekar, rebab). Jakarta: Gema Nada Pertiwi/ Keraton KR 031, 1970 . 